Gut, 1973, 14, 923-926

\title{
A controlled therapeutic trial of long-term maintenance treatment of ulcerative colitis with sulphasalazine (Salazopyrin)
}

\author{
A. S. DISSANAYAKE AND S. C. TRUELOVE \\ From the Nuffield Department of Clinical Medicine, Radcliffe Infirmary, Oxford
}

SUMMARY Sixty-four patients with proven ulcerative colitis who had been maintained on sulphasalazine as their sole form of treatment for a minimum period of one year were entered into a controlled trial of sulphasalazine versus dummy tablets for a period of six months. All the patients admitted were not only symptom-free but also showed no evidence of inflammation on sigmoidoscopy and rectal biopsy. A patient was judged to have relapsed when there was a recurrence of colitic symptoms accompanied by sigmoidoscopic and histological evidence of inflammation.

The patients who received dummy tablets had more than four times the relapse rate of those receiving sulphasalazine. The results were similar in patients who had been on maintenance treatment with sulphasalazine for less than three years before entry into the trial and in those who had been on this treatment for more than three years.

It is concluded that maintenance treatment of ulcerative colitis with sulphasalazine should be continued indefinitely unless contraindicated by side effects.

Sulphasalazine (Salazopyrin) was first used for the treatment of ulcerative colitis by Svartz (1942) and it has become an accepted form of medical treatment for the disease. A controlled therapeutic trial has shown that it has some value in the treatment of an actual attack of colitis (Baron, Connell, LennardJones, and Jones, 1962). However, other controlled therapeutic trials have shown that corticosteroid therapy is superior to sulphasalazine for the rapid checking of an actual attack (Lennard-Jones, Longmore, Newell, Wilson, and Jones, 1960; Truelove, Watkinson, and Draper, 1962). The position is reversed when one considers maintenance treatment for the prevention of relapses. Controlled therapeutic trials have shown that cortisone in a daily dose of $50 \mathrm{mg}$ for one year and also prednisolone in a daily dose of $15 \mathrm{mg}$ are totally ineffective in reducing the number of recurrences (Truelove and Witts, 1959; Lennard-Jones, Misiewicz, Connell, Baron, and Jones, 1965). By contrast, a controlled therapeutic trial of sulphasalazine in a dose of $0.5 \mathrm{~g}$ four times a day over the course of one year was shown to reduce the relapse rate sharply (Misiewicz, Lennard-Jones, Connell, Baron, and Jones, 1965).

Received for publication 17 September 1973.
Since then, it has become common to employ maintenance treatment with sulphasalazine and the question now arises as to how long such maintenance treatment should be continued.

\section{Plan of Study}

The patients selected for entry into the therapeutic trial were all patients with proven ulcerative colitis who were enjoying a prolonged remission while on maintenance treatment with sulphasalazine, the usual dose being $0.5 \mathrm{~g}$ four times a day. In addition to being symptom-free, it was necessary for sigmoidoscopy to show normal mucosal appearances and a rectal biopsy to show no significant inflammation. Patients who fulfilled these three criteria were invited to volunteer for the study. If they agreed to do so, blood was taken for the following tests: (1) full blood count using a Coulter counter; (2) ESR by the Westergren method; (3) SMA biochemical profile using a Technicon 12/60 AutoAnalyzer.

On entry to the study, they were prescribed Salazopyrin Special one tablet four times a day for a period of six months. A stratified design was used with the strata corresponding to the number of years the patients had been maintained on sulphasalazine 
therapy, with a single stratum for those who had been on it for more than five years. Within each stratum, patients were allotted at random either to real sulphasalazine tablets or to dummy tablets of identical appearance, employing a system of restricted randomization to keep the numbers roughly equal in the treated and control groups in each stratum. The master sheet indicating the type of tablet to be issued to individual patients was held by the hospital pharmacist. The physicians and the patients were unaware of the nature of the therapy and the pathologist who examined the rectal biopsy specimens was likewise unaware. The code was not broken until the entire trial was completed.

Assuming that a patient kept well, he was seen again at three months and at six months after entry into the trial. At the three-month appointment blood was taken chiefly for the purpose of seeing whether the patients on real Salazopyrin tablets were taking them, as judged by the presence of salicylates and sulphapyridine and its metabolites in the serum. At the six-months appointment, all the patients were examined by sigmoidoscopy and rectal biopsy and the blood examinations were repeated.

Patients were told to report back without delay if they suffered from a recurrence of colitis symptoms. Such patients were examined by sigmoidoscopy and rectal biopsy and the blood examinations were repeated. They were classified as failures if there was definite evidence of inflammation. If so, they were taken out of the trial. The attack was treated with oral prednisolone and a topical corticosteroid and the patient was returned to maintenance treatment with sulphasalazine.

\section{Results}

Sixty-four patients were included in the study. The minimum period of previous maintenance treatment with sulphasalazine was one year while, at the other end of the scale, there were patients who had been on it for more than five years.

Table I and fig 1 show the relapse rate for the two treatment groups. More than half the patients who received dummy tablets relapsed during the six-

\begin{tabular}{llcl}
\hline $\begin{array}{l}\text { Type of } \\
\text { Treatment }\end{array}$ & $\begin{array}{l}\text { No. of } \\
\text { Patients }\end{array}$ & $\begin{array}{l}\text { No. } \\
\text { Relapsing }\end{array}$ & $\begin{array}{l}\text { Significance of } \\
\text { Difference }\end{array}$ \\
\hline Sulphasalazine & 33 & $4(12 \cdot 1 \%)$ & $\begin{array}{l}x^{2}=13.2 \\
\mathrm{n}=1\end{array}$ \\
Dummy tablets & 31 & $17(54.8 \%)$ & \begin{tabular}{l}
$\mathrm{P}<0.001$ \\
\hline
\end{tabular}
\end{tabular}

Table I Proportion of patients in the two treatment groups who suffered from a relapse during the trial period

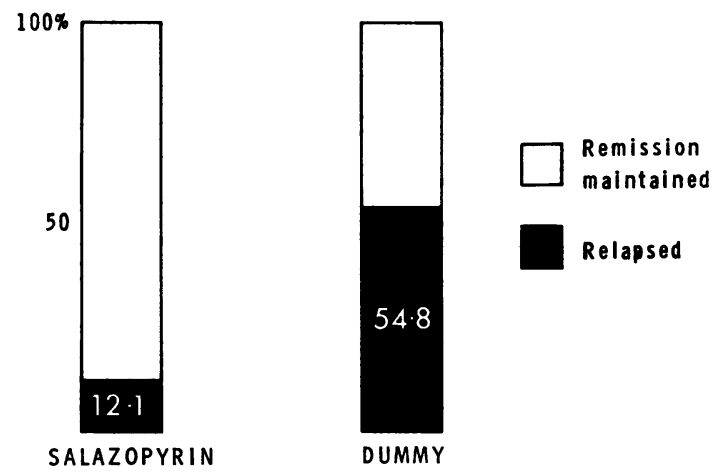

Fig 1 Results for the whole series.

month trial period, which was more than four times the relapse rate of the group receiving sulphasalazine.

Table II and fig 2 show that the results were closely similar whether the patients had been maintained previously for a shorter period of one to three years or a longer period of more than three years.

\section{BLOOD CHANGES}

Table III shows the values before and at the end of the trial period or at the time of relapse. The haemoglobin values did not change significantly in either treatment group, which is perhaps not surprising as any patient who developed a relapse was assessed without delay and removed from the trial. Similarly, the white cell count showed no appreciable differences. The mean value for the ESR showed a significant rise in the dummy-treated group $(P=$ 0.005), which reflects the fact that some of the patients who relapsed had appreciable elevations in the ESR and such relapses were much more common in tine dummy-treated group.

CHECK ON WHETHER THE PATIENTS WERE

TAKING THE CORRECT TABLETS

As already mentioned in the plan of the study, a sample of blood was taken halfway through the trial period (or at the time of relapse if this occurred earlier) in order to check whether the patients were taking the tablets correctly. The serum of every patient who was on real sulphasalazine therapy was found to contain detectable amounts of sulphapyridine and its metabolites and also salicylate. None of the patients on the dummy tablets had detectable amounts of sulphapyridine or its metabolites in the serum. Four patients showed small amounts of salicylate which we attribute to self- 


\begin{tabular}{|c|c|c|c|c|}
\hline $\begin{array}{l}\text { Length of Previous } \\
\text { Maintenance Treatment } \\
\text { with Sulphasalazine (yr) }\end{array}$ & Trial Treatment & No. of Patients & No. Relapsing & Significance of Difference \\
\hline & Dummy & 19 & $10(52.6 \%)$ & $\begin{array}{l}x^{2}=7.27 \\
n=1 \\
P<0.01\end{array}$ \\
\hline More than 3 & $\begin{array}{l}\text { Sulphasalazine } \\
\text { Dummy }\end{array}$ & $\begin{array}{l}15 \\
12\end{array}$ & $\begin{array}{l}2(13.3 \%) \\
7(58.3 \%)\end{array}$ & $\begin{array}{l}P=0.038 \\
\text { (exact probability) }\end{array}$ \\
\hline
\end{tabular}

Table II Results in relation to length of previous maintenance treatment with sulphasalazine

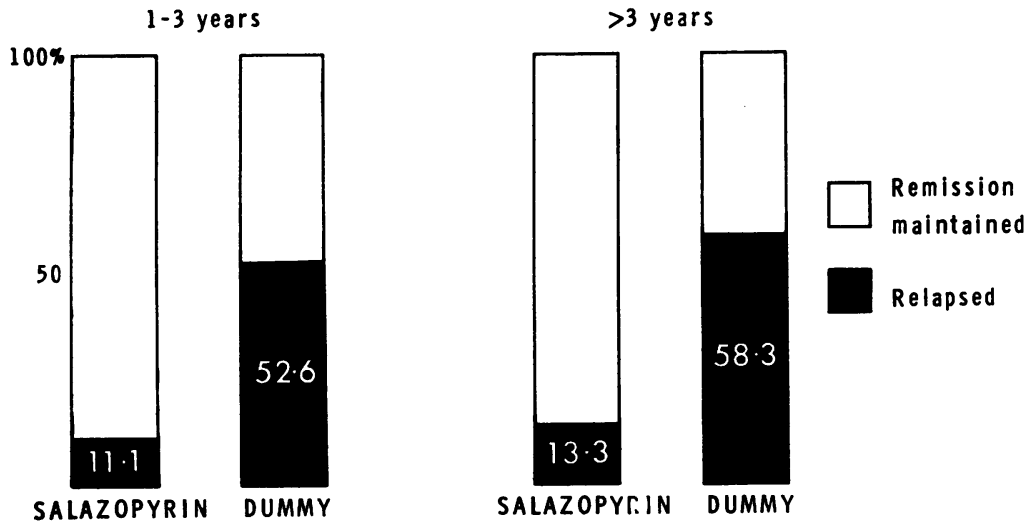

Fig 2 Results in relation to length of previous maintenance therapy with sulphasalazine medication with aspirin for headaches or other symptoms unrelated to the colitis.

These estimations were performed by $\mathrm{Mr} \mathbf{M}$. Ryan in the Nuffield Department of Clinical Biochemistry and were performed without him knowing what form of treatment the individual patients were receiving.

\section{SIDE EFFECTS}

Three patients experienced symptoms after entering the trial, which they attributed to the new tablets. Two patients experienced some nausea while the third developed headaches. In the event, when the code was broken they were all found to have been on sulphasalazine tablets in the same dose as they had previously received for years. The symptoms ceased when they went back on open therapy with known sulphasalazine. They illustrate the operation of psychological factors whenever an experimental situation is created.

\section{COMPARABILITY OF TREATED AND CONTROL GROUPS}

The two groups were closely similar in respect of all of the following factors: age, sex, length of history of ulcerative colitis, severity of the first attack, and maximum extent of disease as judged radiologically.

We therefore conclude that the striking difference in the relapse rate between the two treatment groups was directly due to the suppressive action of sulphasalazine and not due to extraneous factors.

\begin{tabular}{|c|c|c|c|c|c|c|c|c|}
\hline & \multicolumn{4}{|c|}{ Sulphasalazine } & \multicolumn{4}{|c|}{ Dummy } \\
\hline & \multicolumn{2}{|l|}{ Before } & \multicolumn{2}{|l|}{ After } & \multicolumn{2}{|l|}{ Before } & \multicolumn{2}{|l|}{ After } \\
\hline & $\begin{array}{l}\text { Mean } \\
\text { Value }\end{array}$ & $\begin{array}{l}\text { Standard } \\
\text { Error of } \\
\text { the Mean }\end{array}$ & $\begin{array}{l}\text { Mean } \\
\text { Value }\end{array}$ & $\begin{array}{l}\text { Standard } \\
\text { Error of } \\
\text { the Mean }\end{array}$ & $\begin{array}{l}\text { Mean } \\
\text { Value }\end{array}$ & $\begin{array}{l}\text { Standard } \\
\text { Error of } \\
\text { the Mean }\end{array}$ & $\begin{array}{l}\text { Mean } \\
\text { Value }\end{array}$ & $\begin{array}{l}\text { Standard } \\
\text { Error of } \\
\text { the Mean }\end{array}$ \\
\hline $\begin{array}{l}\text { Haemoglobin } \\
(\mathrm{g} / 100 \mathrm{ml})\end{array}$ & $14 \cdot 2$ & 0.2 & $14 \cdot 4$ & $0 \cdot 2$ & 13.9 & 0.3 & $14 \cdot 5$ & $0 \cdot 3$ \\
\hline $\begin{array}{l}\text { White cell count } \\
\text { (cells per c mm) }\end{array}$ & 6140 & 275 & 6056 & 171 & 6444 & 352 & 6851 & 260 \\
\hline $\begin{array}{l}\text { ESR (mm per hour } \\
\text { Westergren) }\end{array}$ & $8 \cdot 6$ & $1 \cdot 8$ & $6 \cdot 7$ & $1 \cdot 5$ & $6 \cdot 6$ & $1 \cdot 0$ & $11 \cdot 6$ & $2 \cdot 1$ \\
\hline
\end{tabular}

Table III Mean haemoglobin values, white cell counts, and ESR immediately before and at the end of the trial period or at time of relapse 


\section{Discussion}

The only other controlled trial of long-term maintenance treatment of ulcerative colitis with sulphasalazine is a recent Scandinavian study by Riis, Anthonisen, Wulff, Folkenborg, Bonnevie, and Binder (1973). Their results were quite different from our own. Whereas we have found that long-term maintenance treatment with suphasalazine continues to have a major effect in reducing recurrences over a period of at least several years, they found only a minor beneficial effect which was not statistically significant. They concluded that, when a patient has been symptom-free for one year on maintenance treatment with sulphasalazine, it is safe to stop the treatment.

It is necessary to consider why there is such a sharp discrepancy between the results of the two studies. Riis et al (1973) resembled us in selecting patients who had been on maintenance treatment with sulphasalazine for a minimum period of one year and in allotting them at random to real or dummy tablets for a period of six months. They also used a stratified design similar to our own. However, there were major differences in the criteria used for regarding a patient as suitable for inclusion in the therapeutic trial and in the criteria used for defining a relapse. Whereas we demanded that a patient should not only be symptom free but also show normal sigmoidoscopic appearances and no significant inflammation on rectal biopsy before being judged suitable for inclusion, they admitted any patient who was symptom free. As far as defining a relapse was concerned, they relied solely on symptoms, taking the passage of blood per rectum on three consecutive days or the passage of three or more stools a day for more than five days as indicating a relapse. By contrast, we demanded not only a return of colitic symptoms but also definite evidence of inflammation on sigmoidoscopy and on rectal biopsy. All the rectal biopsy specimens were examined by one pathologist, who has great experience in this field and who reported on them without knowledge of the clinical state of the patient. We regard our own criteria as more precise and objective than those of Riis et al (1973) and we consider that there is a good case for continuing maintenance treatment with sulphasalazine indefinitely provided there are no harmful side effects.

We are grateful to our pathologist colleague, $\mathrm{Dr}$ Richard Whitehead, for reporting on the rectal biopsy specimens and to Mr Michael Ryan for making the biochemical check on the patients' sera. Pharmacia (G.B.) Ltd made a gift of the Salazopyrin tablets. We are indebted to Aspro Nicholas who made a gift of the dummy tablets which they formulated specially for this study. We wish to thank Miss Craig, Chief Pharmacist to the Radcliffe Infirmary, and her staff for holding the master sheet and issuing the trial tablets.

Baron, J. H., Connell, A. M., Lennard-Jones, J. E., and Avery Jones, F. (1962). Sulphasalazine and salicylazosulphadimidine in ulcerative colitis. Lancet, 1, 1094-1096.

Lennard-Jones, J. E., Longmore, A. J., Newell, A. C., Wilson, C. W. E. and Jones, F. A. (1960). An assessment of prednisone, salazopyrin and topical hydrocortisone hemisuccinate used as outpatient treatment for ulcerative colitis. Gut, 1, 217-222.

Lennard-Jones, J. E., Misiewicz, J. J., Connell, A. M., Baron, J. H., and Jones, F. A. (1965). Prednisone as maintenance treatment for ulcerative colitis in remission. Lancet, 1, 188-189.

Misiewicz, J. J., Lennard-Jones, J. E., Connell, A. M., Baron, J. H., and Jones, F. A. (1965). Controlled trial of sulphasalazine in maintenance therapy of ulcerative colitis. Lancet, 1, 185-188.

Riis, P., Anthonisen, P., Wulf, H. R., Folkenborg, O., Bonnevie, O., and Binder, V. (1973). The prophylactic effect of salazosulphapyridine in ulcerative colitis during long-term treatment. Scand. J. Gastroent., 8, 71-74.

Svartz, N. (1942). Salazopyrin, a new sulfanilamide preparation. A. Therapeutic results in rheumatic polyarthritis. B. Therapeutic results in ulcerative colitis. C. Toxic manifestations in treatment with sulfanilamide preparations. Acta med. scand., $110,577-598$.

Truelove, S. C., Watkinson, G., and Draper, G. (1962). Comparison of corticosteroid and sulphasalazine therapy in ulcerative colitis. Brit. med. J., 2, 1708-1711.

Truelove, S. C., and Witts, L. J. (1959). Cortisone and corticotrophin in ulcerative colitis. Brit. med. J., 1, 387-394.
} 